
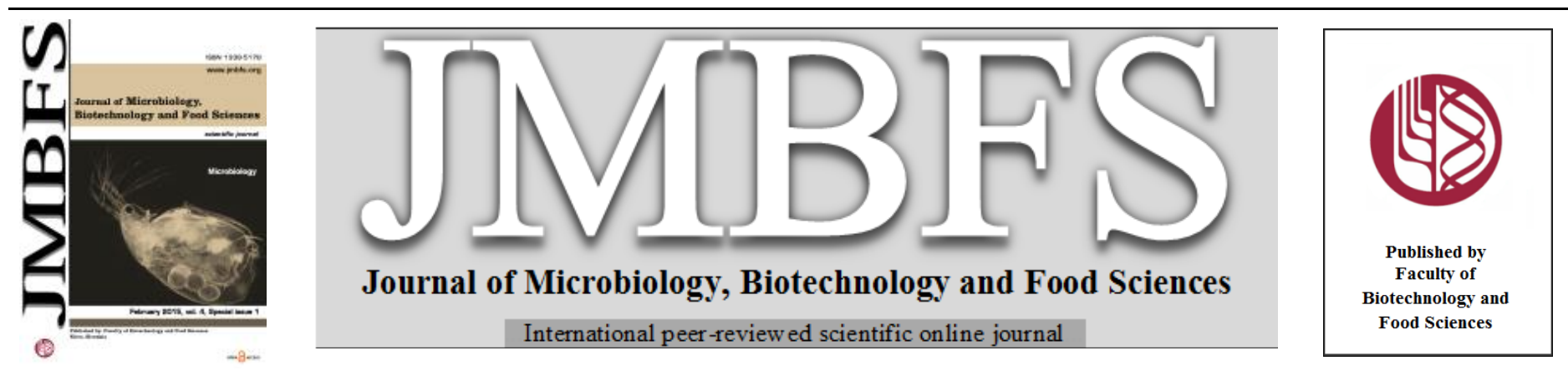

\title{
MICROORGANISMS IN SELECTED CONFECTIONARY PRODUCTS DURING THE MANUFACTURING PROCESS
}

\section{Jana Petrovál , Lubomíra Juhaniaková ${ }^{1}$, Margarita Terentjeva ${ }^{2}$, Simona Kunová ${ }^{3}$, Henrieta Blaškovičová $^{1}$, Miroslava Kačániovál $^{*}$}

\section{Address(es):}

${ }^{1}$ Slovak University of Agriculture in Nitra, Faculty of Biotechnology and Food Sciences, Department of Microbiology, Trieda Andreja Hlinku 2, 949 76, Nitra, Slovakia.

${ }^{2}$ Latvia University of Agriculture, Faculty of Veterinary Medicine, Institute of Food and Environmental Hygiene, K. Helmaņa iela 8, LV 3007, Jelgava, Latvia.

${ }^{3}$ Department of Food Hygiene and Safety, Faculty of Biotechnology and Food Sciences, Slovak University of Agriculture in Nitra, Trieda Andreja Hlinku 2, 94976

Nitra, Slovak Republic.

*Corresponding author: miroslava.kacaniova@gmail.com

doi: 10.15414/jmbfs.2015.4.special1.57-61

\section{ARTICLE INFO}

Received 7. 11. 2014

Revised 10. 12. 2014

Accepted 25. 12. 2014

Published 2. 2. 2015

\section{Regular article}

open ${ }_{\text {ACCESS }}$

\begin{abstract}
The aim of our study was to evaluate the microbiological quality confectionery products during production. A total of 135 samples were analyzed: 45 samples of the punch balls, 45 Venček samples and 45 samples French cubes from home, school and private production. For microorganism cultivation VRBL agar for the isolation of coliform bacteria, DRBC and DG18 for microscopic fungi and yeasts, Plate Count Agar for total viable count, Meat peptone agar for mesophilic aerobic bacteria, XLD agar for Salmonella sp. and Baird Parker agar for Staphylococcus aureus were used. Following microbiological parameters were tested: total viable count, mesophilic anaerobic microorganisms, coliform bacteria, yeast and microscopic filamentous fungi, Salmonella spp. and Staphylococcus aureus. Products are assessed according to the limit values of the number of microorganisms contained in the Codex Alimentary of the Slovak Republic. The overall assessment of the microbiological quality of the punch balls, we found that two samples from school factory and one sample from private producer did not meet CA SR for the total viable count. Comparing the microbiological quality of Venček with CA SR, we found that one sample of home production did not meet the requirements for this type of product. All the tested samples were Staphylococcus aureus and Salmonella spp. negative. Comparing the results of the samples with French cubes CA SR, we found that all the samples satisfy requirements.
\end{abstract}

\section{INTRODUCTION}

Due to the chemical composition rich in nutrients and high humidity, the confectionery products are favorable environments for the development of microorganisms. Therefore, respecting the steps of technological process, specific to each group of cakes and respecting the working parameters (time, temperature, and relative air humidity) will ensure the attainment of healthy products which do not endanger to consumers' health. The main objectives of confectionery control system are to: i) protect public health by reducing the risk of food-borne illnesses; ii) protect consumers from unsanitary, unwholesome, mislabeled or adulterated products; and iii) contribute to economic development by maintaining consumer confidence in the food supply. Factors which contribute to potential hazards in confectionery include preparation operations; misuse of chemicals; contaminated raw materials, ingredients and water; inadequate or improper storage, etc. (Visan and Bara, 2010).

Confectionery products are an integral part of the human diet because they can be used as a high density food energy source, it improves the feeling and mood of consumers, and they are an important part of celebrations, festivities and family traditions (Kronberga et al., 2013).For the reduction of microbiological loads and extending shelf life of harvested chestnut combination of freeze drying and chocolate-coating give great result (Gounga and Shi-Chang, 2008). Differences in microbial activities between different heap fermentations can result in dried fermented cocoa beans and chocolates with different flavor characteristics. Flavor of chocolate may control by fermentation control (Machrin and Hetherington, 1999; Camu, 2008). Major routes for the production of flavors are enzymatic and microbial process, that complied with the definition of "natural" in the Federal Register which focused on microorganism, enzymes, substrates, and significant odorants and tastings which is described by Seitz, (1990).

The present study aims were to examine the microbiological quality of three confectionary products made in three different bakeries and to assess their microbiological fitness for human consumption. In confectionery products microbiological parameters of total viable count, coliforms bacteria, mesophilic aerobes bacteria, yeasts and microscopic filamentous fungi were detected.

\section{MATERIAL AND METHODS}

\section{Samples collection}

Total of 135 samples were analyzed, among them were examined 45 samples of the punch balls, 45 Venček samples and 45 samples French cubes produced in home production (HP), in a training classroom of school kitchen (SP) and in private confectionery production center (PP)

\section{Microbiological analyses}

For microbiological analysis the confectionary samples were processed immediately after collection. The total count of bacteria (TCB), mesophilic aerobic bacteria (MAB), coliforms bacteria $(\mathrm{CB})$, yeasts $(\mathrm{Y})$, microscopic filamentous fungi (MF), Staphylococcus aureus (SA) and Salmonella spp. (SS) were assessed. Colony forming unit counting method was applied for quantitative determination of respective groups of microorganisms in $1 \mathrm{~g}$ of confectionery component materials. Serial decimal dilutions of each confectionery component were performed and basic dilution $\left(10^{-1}\right)$ was prepared as follows: $5 \mathrm{~g}$ of confectionery components was added to the bank containing $45 \mathrm{~mL}$ of $0.1 \%$ peptone buffered water. Plate Count Agar was used for CFU counting isolation of TCB and after inoculation agar was incubated for $48-72 \mathrm{~h}$ at $30{ }^{\circ} \mathrm{C}$ applying aerobic cultivation method. Meat peptone agar was used for MAB CFU counting and inoculated agar was incubated for $48-72 \mathrm{~h}$ at $25{ }^{\circ} \mathrm{C}$ applying aerobic cultivation method). Violet Red Bile agar was used for CB CFU counting by incubation of inoculated agar for $24 \mathrm{~h}$ at $37{ }^{\circ} \mathrm{C}$ applying aerobic cultivation method). DRBC and DG18 agars were used for Y and MF CFU counting by incubation of inoculated agars for $5-7$ days at $25^{\circ} \mathrm{C}$ applying aerobic cultivation method). XLD agar was used for isolation of Salmonella spp. by incubation of 
inoculated agar for 18-24 hour at $37 \mathrm{C}$ applying aerobic cultivation method) and Baird Parker agar was used for Staphylococcus aureus isolation by incubation of inoculated agar for $45-48$ hour at $35-37^{\circ} \mathrm{C}$ applying aerobic cultivation method). All cultivating medium were obtained from Biomark ${ }^{\mathrm{TM}}$, Pune, India.

\section{Statistical analysis}

For data from each replication the mean was calculated and all data were log transformed. Statistical analysis was done with STATGRAPHICS 5 software (UMEX GmbH Dresden, Germany). For number of total viable count, mesophilic aerobic bacteria, coliforms bacteria, microscopic filamentous fungi and yeast standard deviation (SD) and coefficient of variability (CV) were calculated. For differences in a numbers of bacteria in confectionary Student's Tukey HSD test was calculated and samples were accepted as significantly different if $\mathrm{P}<0.05$.

\section{RESULTS AND DISCUSSION}

Confectionery products are an significant part of the human diet because they can be used as food energy source, it improves consumers feeling and mood., they are important part of food offer at celebrations, festivities and used at different social and family events . Cakes are most popular pastry products, because they have sufficiently long storage time, good taste, and not very difficult in preparation cake making is no long a complicated procedure. Unfortunately, cakes have high content of fat and sugar, and in result cakes are product with high content of calories, but are low in dietary fiber, vitamins, and minerals and do not correspond the rules of healthy diet. Despite of this the confectionery industry is one of the fastest growing segments in the global food market and this trend will be observed in the future (Kronberga et al., 2013).

Microbial spoilage of confectionary products is primary limited to problems regarding yeast and mold development. This is a reflection of the low moisture and high solids content of confections (Loureiro and Querol, 1999). These two factors are inter-related And the high sugar content of products tends to immobilize the small amounts of water present and make it unavailable for microbial growth. In those instances where microbial activity is seen, it is usually triggered by the presence of moisture in localized areas, and in such cases yeast and mold development is most often seen because these organisms require less water than bacteria (Silliker, 1968).

In punch balls (Fig. 1) from three different production of total viable count ranged from 3.59 in home production to $4.24 \log$ CFU.g ${ }^{-1}$ in private production. The number of mesophilic aerobes bacteria ranged from 2.22 in home production to $2.36 \log$ CFU.g ${ }^{-1}$ in private production, number of coliforms bacteria ranged from 0.04 in home production to $0.77 \log \mathrm{CFU} . \mathrm{g}^{-1}$ in school production and number of microscopic filamentous fungi ranged from 0.78 to $0.92 \log \mathrm{CFU}_{\mathrm{g}} \mathrm{g}^{-1}$ in home production and school production, respectively. Yeasts, Staphylococcus aureus and Salmonella spp. were not found in confectionary products. The Codex Alimentarius of Slovak republic indicates number of coliforms bacteria $\left(10^{3}\right)$ and microscopic fungi $\left(10^{2}\right)$ should not be exceeded. Two samples of punch balls from school production and one from private production were not in accordance with Codex Alimentarius of the Slovak Republic (CA SR, 2009). Statistica significant differences of microbiological quality of punch balls between all production types are summarized in Table 1.
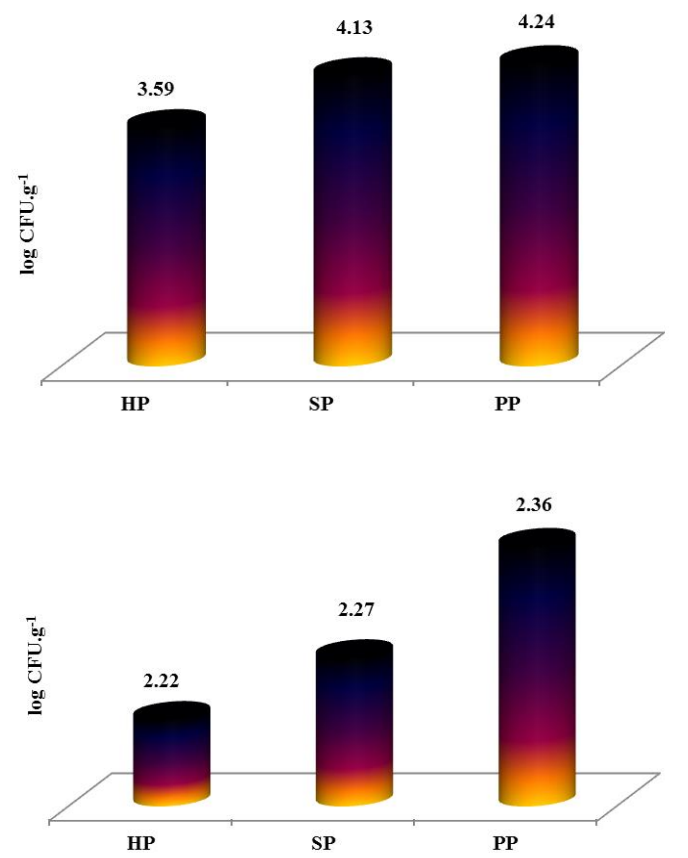

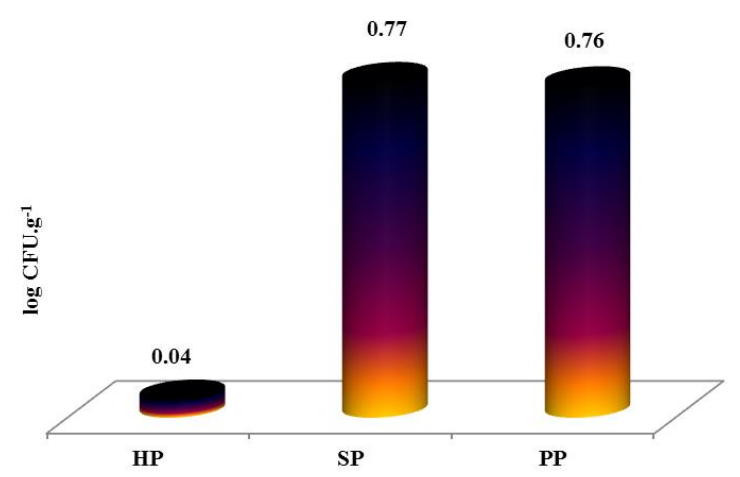

C

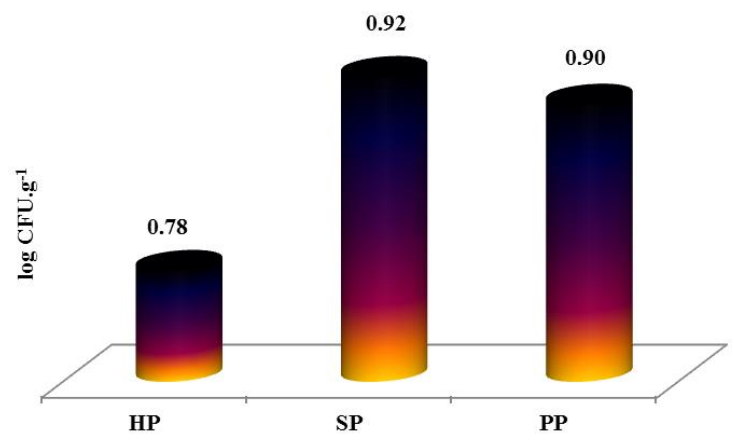

D

Figure 1 Microbiological properties of punch balls (log CFU.g ${ }^{-1}$ )

Legend: A-total viable count, B-mesophilic aerobic bacteria, C-coliform bacteria, Dmicroscopic filamentous fungi, HP-home production, SP-school production, PP-private production

Table 1 Statistically significant differences of the different groups of microorganisms in punch balls

\section{Total viable count}

\begin{tabular}{|c|c|c|c|}
\hline Contrast & Significance & Differences & -/+Limit \\
\hline $\mathrm{HP}-\mathrm{PP}$ & $*$ & -0.646222 & 0.166976 \\
\hline $\mathrm{HP}-\mathrm{SP}$ & $*$ & -0.535556 & 0.166976 \\
\hline $\mathrm{PP}-\mathrm{SP}$ & - & 0.110667 & 0.166976 \\
\hline \multicolumn{4}{|c|}{ Mesophilic aerobic bacteria } \\
\hline Contrast & Significance & Differences & -/+Limit \\
\hline $\mathrm{HP}-\mathrm{PP}$ & - & 0.0835556 & 0.246056 \\
\hline $\mathrm{HP}-\mathrm{SP}$ & - & 0.139333 & 0.246056 \\
\hline $\mathrm{PP}-\mathrm{SP}$ & - & 0.0557778 & 0.246056 \\
\hline \multicolumn{4}{|c|}{ Microscopic filamentous fungi } \\
\hline Contrast & Significance & Differences & -/+Limit \\
\hline $\mathrm{HP}-\mathrm{PP}$ & - & -0.115778 & 0.296145 \\
\hline $\mathrm{HP}-\mathrm{SP}$ & - & -0.145556 & 0.296145 \\
\hline $\mathrm{PP}-\mathrm{SP}$ & - & -0.0297778 & 0.296145 \\
\hline \multicolumn{4}{|c|}{ Coliform bacteria } \\
\hline Contrast & Significance & Differences & -/+Limit \\
\hline $\mathrm{HP}-\mathrm{PP}$ & $*$ & -0.714444 & 0.315014 \\
\hline $\mathrm{HP}-\mathrm{SP}$ & $*$ & -0.727778 & 0.315014 \\
\hline $\mathrm{PP}-\mathrm{SP}$ & - & -0.0133333 & 0.315014 \\
\hline
\end{tabular}

production, PP-private production

In the study Juhaniaková et al. (2014a) the aim of work was to determine microbiological quality and water activity of confectionery products - corpuses of desserts, stuffing cakes and finished cakes. In confectionery products the following microbiological parameters as total count of bacteria, coliforms bacteria, mesophilic aerobic bacteria, yeasts, microscopic filamentous fungi, counts of Staphylococcus aureus and Salmonella spp. were tested. Among confectionery products were evaluated five corpuses of Kremeš, five stuffing of Kremeš and five Venček cakes and microbiological tests these 15 samples of confectionery products were used. The numbers of total count of bacteria ranged from 2.9 to $3.65 \log \mathrm{CFU} . \mathrm{g}^{-1}$, the number of mesophilic aerobic bacteria ranged from 2.00 to $3.28 \mathrm{log} \mathrm{CFU} . \mathrm{g}^{-1}$, coliforms bacteria in confectionery products ranged from 0.00 to $3.15 \mathrm{CFU.g}^{-1}$, number of yeasts ranged from 0.00 to $3.30 \mathrm{log}$ CFU.g ${ }^{-1}$ and the number of microscopic fungi ranged from 0.00 to 2.90 CFU.g ${ }^{-1}$. None of the samples showed any growth of Staphylococcus aureus and Salmonella spp. and results are in line with our study. Microbiological quality of eight out of 15 investigated samples of confectionary products were in accordance with the Codex Alimentarius of the Slovak Republic.

In Venček (Fig. 2) from three different production of total viable count ranged 
from 3.72 in school production to $3.89 \log \mathrm{CFU}_{\mathrm{g}}{ }^{-1}$ in home production. The number of mesophilic aerobes bacteria ranged from 2.08 in home production to $2.37 \log$ CFU. $\mathrm{g}^{-1}$ in private production, number of coliforms bacteria ranged from 0.80 in home production to $1.05 \log \mathrm{CFU} \cdot \mathrm{g}^{-1}$ in school production, number of yeast ranged from 0.20 in private production to $0.38 \mathrm{log} \mathrm{CFU}_{\mathrm{g}}{ }^{-1}$ in home production and number of microscopic filamentous fungi ranged from 0.25 in school production to $0.52 \mathrm{log}$ CFU.g ${ }^{-1}$ in home production. Staphylococcus aureus and Salmonella spp. were not found in confectionary products samples in the present study. The Codex Alimentarius of Slovak republic indicates number of coliforms bacteria $\left(10^{3}\right)$ and microscopic fungi $\left(10^{2}\right)$ in confectionary products and one sample of Venček from home production was not accordance with Codex Alimentarius of the Slovak Republic (CA SR, 2009). Statistical significant differences in microbiological quality of Venček between all production types are summarized in Table 2.
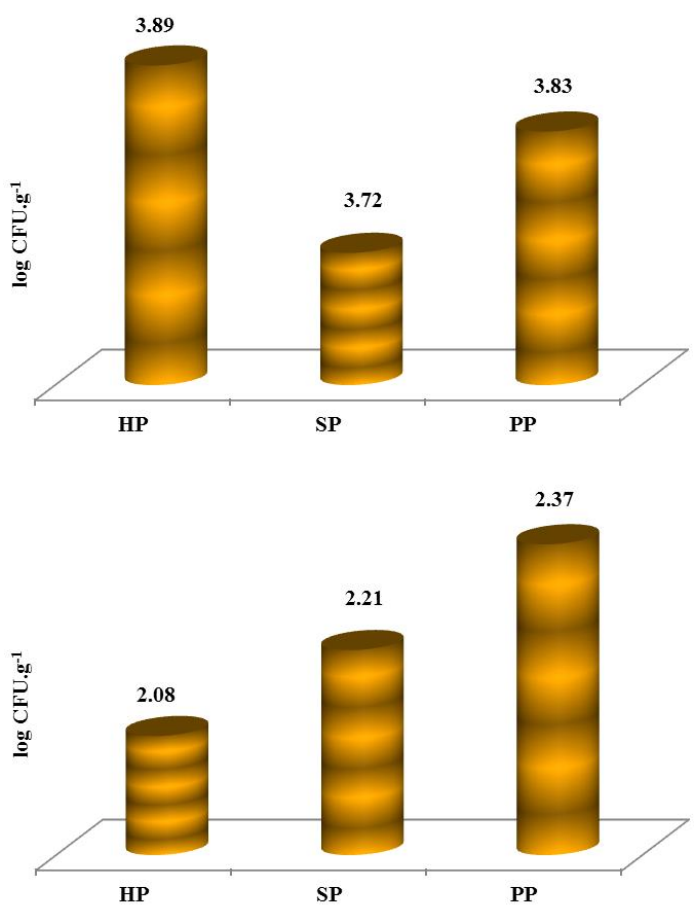

B

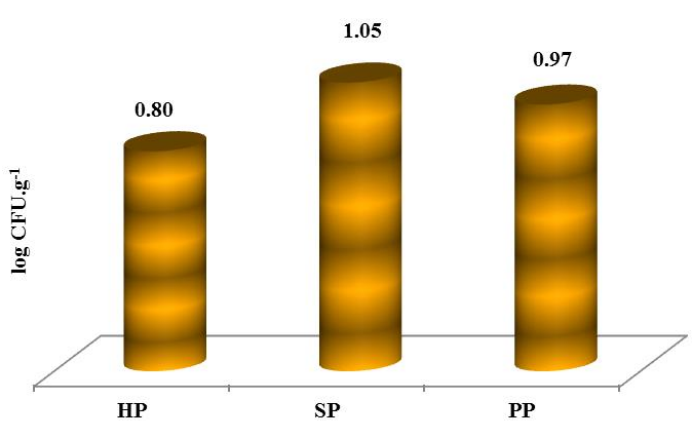

C

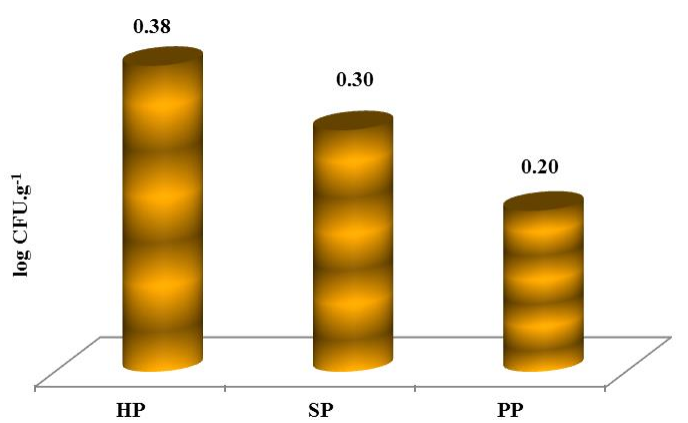

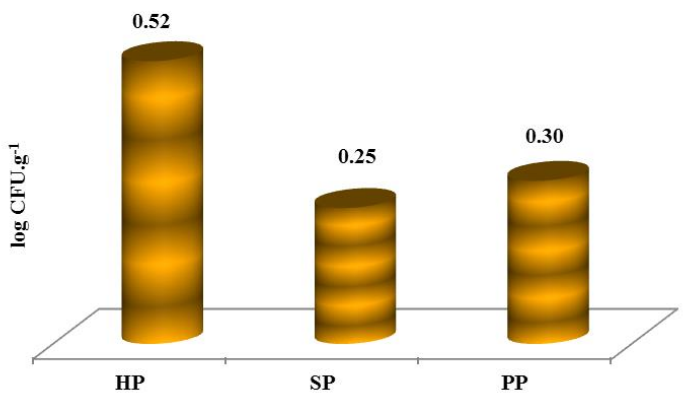

$\mathbf{E}$

Figure 2 Microbiological properties of Venček $\left(\log\right.$ CFU.g $\left.{ }^{-1}\right)$

Legend: A-total viable count, B-mesophilic aerobic bacteria, C-coliform bacteria, D-yeast, Emicroscopic filamentous fungi, HP-home production, SP-school production, PP-private production

Table2 Statistically significant differences of the different groups of microorganisms in Venček

\begin{tabular}{|c|c|c|c|}
\hline \multicolumn{4}{|c|}{ Total viable count } \\
\hline Contrast & Significance & Differences & -/+Limit \\
\hline $\mathrm{HP}-\mathrm{PP}$ & - & 0.176667 & 0.199971 \\
\hline $\mathrm{HP}-\mathrm{SP}$ & - & 0.0611111 & 0.199971 \\
\hline $\mathrm{PP}-\mathrm{SP}$ & - & -0.115556 & 0.199971 \\
\hline \multicolumn{4}{|c|}{ Mesophilic aerobic bacteria } \\
\hline Contrast & Significance & Differences & -/+Limit \\
\hline $\mathrm{HP}-\mathrm{PP}$ & - & -0.286 & 0.294071 \\
\hline $\mathrm{HP}-\mathrm{SP}$ & - & -0.131556 & 0.294071 \\
\hline $\mathrm{PP}-\mathrm{SP}$ & - & 0.154444 & 0.294071 \\
\hline \multicolumn{4}{|c|}{ Microscopic filamentous fungi } \\
\hline Contrast & Significance & Differences & -/+Limit \\
\hline $\mathrm{HP}-\mathrm{PP}$ & $*$ & 0.270667 & 0.253725 \\
\hline $\mathrm{HP}-\mathrm{SP}$ & - & 0.225111 & 0.253725 \\
\hline $\mathrm{PP}-\mathrm{SP}$ & - & -0.0455556 & 0.253725 \\
\hline \multicolumn{4}{|c|}{ Coliform bacteria } \\
\hline Contrast & Significance & Differences & -/+Limit \\
\hline $\mathrm{HP}-\mathrm{PP}$ & - & -0.167333 & 0.339446 \\
\hline $\mathrm{HP}-\mathrm{SP}$ & - & -0.242444 & 0.339446 \\
\hline $\mathrm{PP}-\mathrm{SP}$ & - & -0.0751111 & 0.339446 \\
\hline \multicolumn{4}{|l|}{ Yeast } \\
\hline Contrast & Significance & Differences & -/+Limit \\
\hline $\mathrm{HP}-\mathrm{PP}$ & - & 0.174222 & 0.244012 \\
\hline $\mathrm{HP}-\mathrm{SP}$ & - & 0.0742222 & 0.244012 \\
\hline$P P-S P$ & - & -0.1 & 0.244012 \\
\hline
\end{tabular}

Legend: *statistical significant differences $(\mathrm{P} \leq 0.05)$, HP-home production, SP-schoo production, PP-private production

In the study Juhaniaková et al. (2013) microbiological quality of confectionary from two different productions - manufacture and private was assessed. The better microbiological quality of confectionary products in all microbial parameters tested was in private production. Understanding the nature of microorganisms (including their sources and growth characteristics) is key to microbial control in confectionery products. Microorganisms gain access to foodprocessing areas through multiple routes (e.g., raw materials, personnel and equipment traffic, water leaks and pests). Failure to implement appropriate and effective process and sanitation control could allow these microorganisms, including pathogens, to become established in the processing environment where they may be able to survive for extended periods of time and re-contaminate product.

In French cubes (Fig. 3) from three different production of total viable count ranged from 3.53 in home production to $3.90 \log$ CFU. ${ }^{-1}$ in school production. The number of mesophilic aerobes bacteria ranged from 2.06 in private production to $2.16 \log$ CFU. $\mathrm{g}^{-1}$ in home production, number of coliforms bacteria ranged from 0.41 in private production to $0.55 \mathrm{log}$ CFU.g ${ }^{-1}$ in home production, number of yeast ranged from 0.00 in school production to $0.57 \log$ CFU.g ${ }^{-1}$ in home production and number of microscopic filamentous fungi ranged from 0.32 in home production to $1.01 \mathrm{log}$ CFU.g ${ }^{-1}$ in school production. Staphylococcus aureus and Salmonella spp. were not found in confectionary products samples. All samples of French cubes were in accordance with Codex Alimentarius of the Slovak Republic (CA SR, 2009). Statistical significant differences of French cubes between all production types are summarized in Table 3 . 


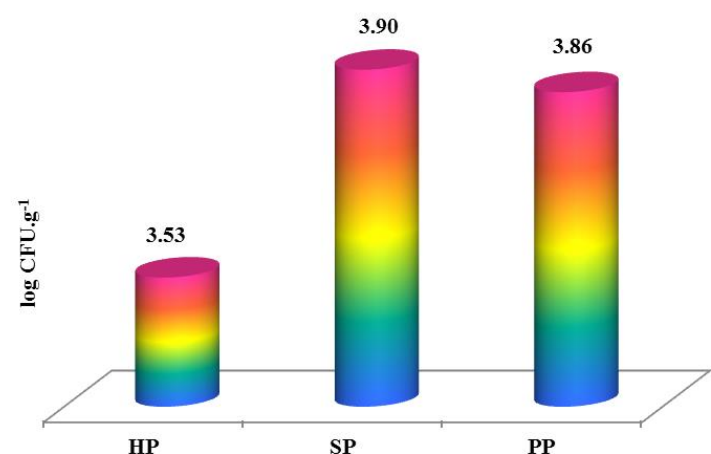

HP

A

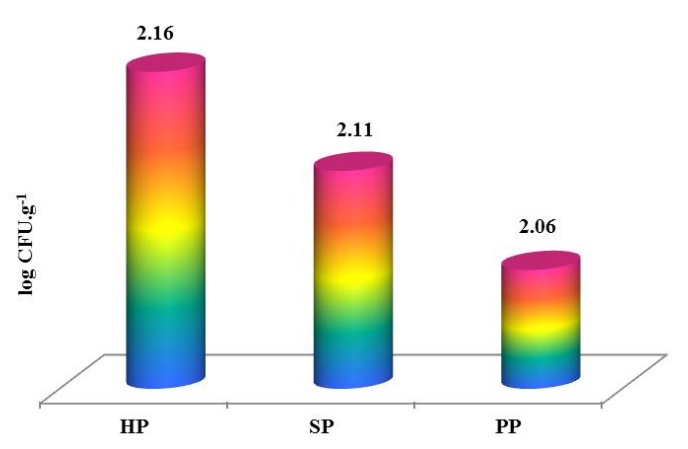

B

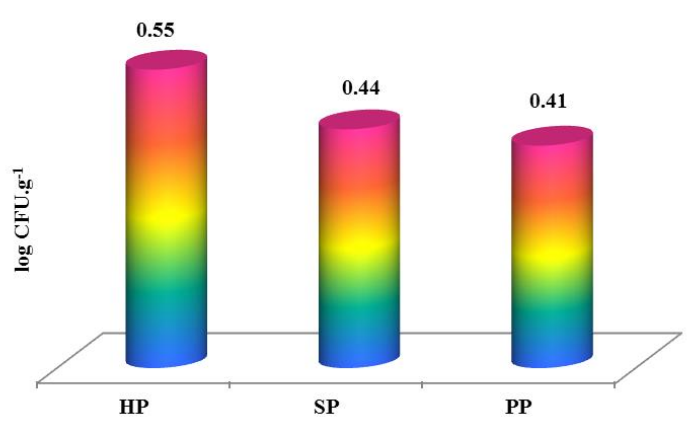

C

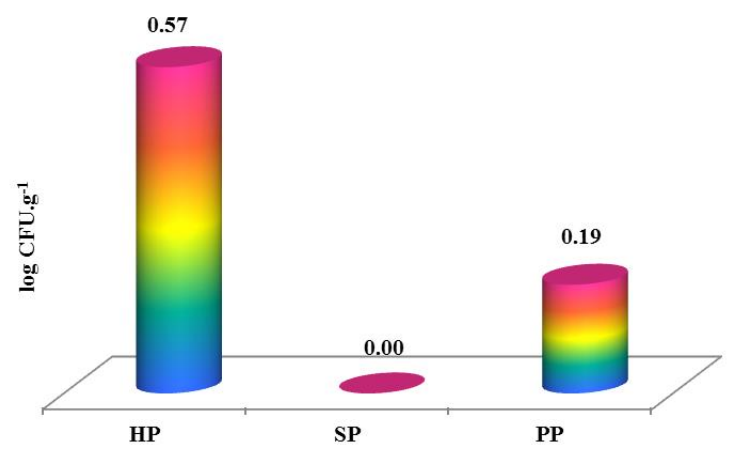

D

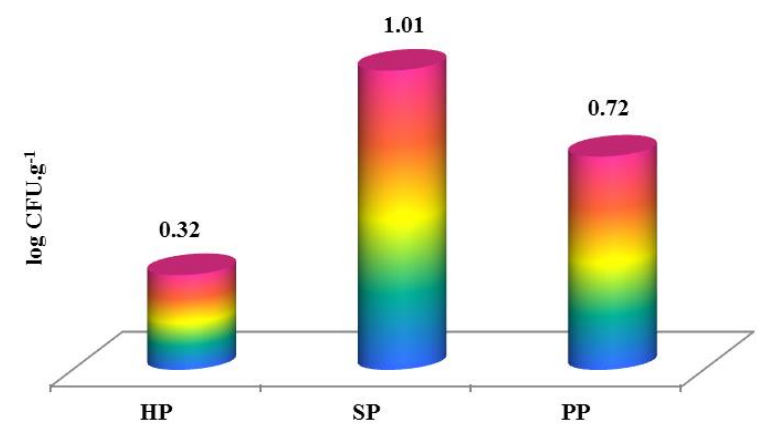

$\mathbf{E}$

Figure 3 Microbiological properties of French cubes (log CFU.g $\left.{ }^{-1}\right)$

Legend: A-total viable count, B-mesophilic aerobic bacteria, C-coliform bacteria, D-yeast, Emicroscopic filamentous fungi, HP-home production, SP-school production, PP-private production
In Juhaniaková et al. (2013) study microbiological quality and water activity of confectionery products as coconut balls was tested. In confectionery products microbiological parameters: total count of bacteria, coliforms bacteria mesophilic aerobic bacteria, yeasts, microscopic filamentous fungi, counts of Staphylococcus aureus and Salmonella spp. were studied in 10samples of coconut balls. The total count of bacteria in coconut ball samples ranged from 3.00 to $3.74 \log$ CFU.g ${ }^{-1}$, the number of mesophilic aerobic bacteria ranged from 2.00 to $2.95 \log \mathrm{CFU} . \mathrm{g}^{-1}$, the number of coliforms bacteria ranged from 2.00 to $2.70 \log$ CFU.g ${ }^{-1}$, the number of microscopic filamentous fungi ranged from 2.00 to $2.60 \log$ CFU.g ${ }^{-1}$, which were higher than in our study.

Table 3 Statistically significant differences of the different groups of microorganisms in French cubes

\section{Total viable count}

\begin{tabular}{|l|c|c|c|}
\hline Contrast & Significance & Differences & -/+Limit \\
\hline $\mathrm{HP}-\mathrm{PP}$ & $*$ & -0.372889 & 0.24395 \\
\hline $\mathrm{HP}-\mathrm{SP}$ & $*$ & -0.331111 & 0.24395 \\
\hline $\mathrm{PP}-\mathrm{SP}$ & - & 0.0417778 & 0.24395 \\
\hline
\end{tabular}

\section{Mesophilic aerobic bacteria}

\begin{tabular}{|l|c|c|c|}
\hline Contrast & Significance & Differences & -/+Limit \\
\hline HP - PP & - & 0.103111 & 0.267335 \\
\hline HP - SP & - & 0.044 & 0.267335 \\
\hline PP - SP & - & -0.0591111 & 0.267335 \\
\hline
\end{tabular}

Microscopic filamentous fungi

\begin{tabular}{|l|c|c|c|}
\hline \hline Contrast & Significance & Differences & -/+Limit \\
\hline HP - PP & $*$ & -0.402889 & 0.278743 \\
\hline HP - SP & $*$ & -0.695778 & 0.278743 \\
\hline PP - SP & $*$ & -0.292889 & 0.278743 \\
\hline Coliform bacteria & & & \\
\hline
\end{tabular}

\begin{tabular}{|l|l|l|l|} 
Coliform bacteria & \multicolumn{1}{|l|}{-/+Limit } \\
\hline \hline Contrast & Significance & Differences & -
\end{tabular}

\begin{tabular}{|l|c|c|c|}
\hline Contrast & Significance & Differences & -/+Limit \\
\hline HP - PP & - & 0.14 & 0.302834 \\
\hline HP - SP & - & 0.111111 & 0.302834 \\
\hline PP - SP & - & $-0 ., 0288889$ & 0.302834 \\
\hline Yeast & \multicolumn{3}{|l}{} \\
\hline \hline Contrast & Significance & Differences & -/+Limit \\
\hline HP - PP & $*$ & 0.374 & 0.223785 \\
\hline HP - SP & $*$ & 0.568 & 0.223785 \\
\hline PP - SP & - & 0.194 & 0.223785 \\
\hline
\end{tabular}

Legend: *statistical significant differences $(\mathrm{P} \leq 0.05)$, HP-home production, SP-school production, PP-private production

The better microbiological quality of punch ball was in home production and also they had the best quality among the tested confectionary products Understanding the nature of microorganisms (including their sources and growth characteristics) is key to microbial control in confectionery products (Juhaniaková et al., 2014b).

The control of raw materials, processing and environment are critical factors in the prevention of microbial contamination in confectionery. Salmonella and Staphylococcus aureus has been found to be the major hazard in confectionery.

Testing for this organisms at specific control points provide the best means of quality control (Kačániová and Juhaniaková, 2011).

The control of raw materials, processing and environment are critical factors in the prevention of microbial contamination in confectionery. Confidence in the safety and integrity of the food supply is an important requirement for consumers (Doyle et al., 2000). Food-borne disease outbreaks involving agents such as Escherichia coli, Salmonella, Bacillus cereus, Staphylococcus, Listeria and chemical contaminants highlight problems with food safety and increase public anxiety that modern farming systems, food processing and marketing do not provide adequate safeguards for public health. Constant surveillance and good manufacturing practice are the best methods for prevention of contamination.

\section{CONCLUSION}

The overall assessment of the microbiological quality of the punch balls, we found that two samples from school production and one sample from private production were not meet CA SR requirements for the total number of microorganisms. Comparing the microbiological quality of Venček with CA SR, we found that one sample of home production was not in accordance with requirements for this type of product. Comparing the results of French cubes CA $\mathrm{SR}$, we found that all samples were meet CA SR requirements and from 135 samples only four were not comply Codex Alimentarius requirements and the quality of the confectionary products was acceptable.

Acknowledgments: The paper was supported by the project: The research leading to these results has received funding from the European Community under project no 26220220180: Building Research Centre „AgroBioTech“ and by grant of VEGA 1/0611/14. 


\section{REFERENCES}

CAMU, N. 2008. Fermentation of cocoa beans: influence of microbial activities and polyphenol concentrations on the flavour of chocolate. Journal of the Science and Food and 97.http://onlinelibrary.wiley.com/doi/10.1002/jsfa.3349/pdf.

CODEX ALIMENTRIUS SR 2009. - Druhá čast', Štvrtá hlava Mikrobiologicképožiadavky na potraviny a na obaly na ich balenie. 2009. [on line]. [cit. 2009-11-07]. Available at <http://www.svssr.sk/sk/legislativa/kodex.asp>.

DOYLE, M.P., RUOFF, K.L., PIERSON, M., WEINBERG, W., SOULE, B., MICHAELS, B.S. 2000. Reducing transmission of infectious agents in the home: Part I. Sources of infection Dairy, Food and Environmental Sanitation, 20, 330337.

GOUNGA, M.E., SHI-CHANG, W.Z. 2008.Nutritional and microbiological evaluations of chocolate-coated Chinese chestnut (Castanea mollissima) fruit for commercial use. Journal of Zhejiang University Science, 9, 675-83.

JUHANIAKOVÁ, L', KAČÁNIOVÁ, M., PETROVÁ, J., KUNOVÁ, S., PAVELKOVÁ, A., BOBKOVÁ, A. 2013. Microbiological quality of confectionary products. Journal of microbiology, biotechnology and food sciences, 2(Special issue 1), 1244-1251

JUHANIAKOVÁ, L`., PETROVÁ, J., HLEBA, L., KUNOVÁ, S., BOBKOVÁ, A., KAČÁNIOVÁ, M. 2014a. Microbiological testing of selected confectionery products quality. Journal of microbiology, biotechnology and food sciences, 3(special issue 1), 225-227.

JUHANIAKOVÁ, L`., PETROVÁ, J., HLEBA, L., KUNOVÁ, S., BOBKOVÁ, A., KAČÁNIOVÁ, M. 2014b. Microbiological analysis of different confectionery products, Journal of microbiology, biotechnology and food sciences, 3 (special issue 1), 228-230.

KAČÁNIOVÁ, M., JUHANIAKOVÁ, L. 2011. Microorganisms in confectionary products. Journal of Microbiology, Biotechnology and Food Sciences, 1(1), 57-69.

KRONBERGA, M., GEDROVICA, I., KARKLINA, D. 2013. The influence of jerusalem artichoke as nutrition value increaser on microbiological parameters of confectionery products. 2013 2nd International Conference on Nutrition and Food Sciences IPCBEE, 53, 16-23.

LOUREIRO, V., QUEROL, A. 1999. The prevalence and control of spoilage yeasts in foods and beverages. Trends in Food Science and Technology, 10(11), 356-365.http://www.sciencedirect.com/science/article/pii/S0924224400000212.

MACHRIN, J.I., HETHERINGTON, M.M. 1999. Mood modulation by food: an exploration of affected and cravings in "chocolate addicts". Brazilian Journal of Clinical Psychology,

34,129

36.http://onlinelibrary.wiley.com/doi/10.1111/j.2044-8260.1995.tb01445.x.

SEITZ, E.W. 1990. Microbial and enzyme-induced flavors in dairy foods Journal of Dairy Sciences, 73, 3664-91.

SILLIKER, J.H. 1968. Microbiological Problems in the Production of Confectionery and Chocolate Products. 22nd P,M.C.A. Production Conference, 1968. http://www.pmca.com/firstpage/1968_20.pdf.

VIŞAN, C.C.,BĂRA, C.J. 2010. Useful microbiological testing of confectionery products quality. Analele Ştiinţifice ale Universităţii „Alexandru Ioan Cuza”, Secţiunea Genetică şi Biologie Moleculară, TOM XI, 2010, 119-123. 